体力科学 (2002) 51，225 234

\title{
EFFECT OF BODY IRON STORES ON INDICES OF BIOSYNTHESIS AND DESTRUCTION OF RED BLOOD CELLS AFTER A SINGLE SESSION OF CYCLING EXERCISE
}

\author{
Yukari Kawano ${ }^{1,3)}$, Akiko Tokashiki ${ }^{2)}$, Yuko Mekata ${ }^{3)}$, Keiko Hayashi ${ }^{3)}$, \\ Harumi Matsumoto ${ }^{4)}$ and IWao Uchiyama ${ }^{5)}$
}

\begin{abstract}
Objectives : The present study investigates the effects of body iron stores upon indices of biosyn. thesis and destruction of red blood cells (RBC) induced by a single session of cycling exercise.

Design: Eight sedentary female students were divided into groups depending on their body iron stores: normal ( $C$ group, $n=5$ ) and iron deficient ( $D$ group, $n=3$ ). Blood samples were collected at five time points of before (pre), immediately after ( 0 hours), then 1,3 and 6 hours after exercise $\left(248 \pm 31 \mathrm{kcal}, 70 \% \dot{\mathrm{VO}}_{2}\right.$ peak level). Osmotic fragility and serum haptoglobin (hp) concentration served as of for degradation, and $\delta$-aminolevulinate dehydratase (ALAD) activity, erythropoietin concentration and number of reticulocytes served as indices of RBC biosynthesis.

Results : A single session of cycling exercise did not affect the level of RBC, hemoglobin, hematocrit, serum iron, ferritin, transferrin saturation, hp and osmotic fragility in either groups. The $\delta-A L A D$ activity increased at $3(\mathrm{p}<0.05)$ and 6 hours $(\mathrm{p}<0.01)$ after exercise compared with that at 0 hours in the $\mathrm{C}$ group. In contrast, $\delta-A L A D$ activity in the $\mathrm{D}$ group was significantly lower at 3 hours after exercise than that of $C$ group $(p<0.001)$. Reticulocytes and erythropoietin concentration increased gradually in the $C$ group after exercise, but not in the $D$ group.

Conclusions : A single session of cycling exercise under our experimental conditions enhanced RBC biosynthesis indicated by $\delta$-ALAD activity, whereas exercise-induced hemolysis was not evident. Body iron stores affect the $\delta$-ALAD activity induced by a single bout of cycling exercise.
\end{abstract}

(Jpn. J. Phys. Fitness Sports Med. 2002, $51: 225 \sim 234$ )

key word : Red blood cells, body iron stores, osmotic fragility, haptoglobin, $\delta$-aminolevulinate dehydratase, single session of cycling exercise

\section{Introduction}

Iron plays key roles in oxygen transport, and in intracellular enzymatic processes involving mitochondrial electron transport or oxidative phosphorylation as a cofactor. One of the most crucial issues among female athletes is an iron de. ficiency.

Increased physical activities may augment iron demand ${ }^{1)}$. The rate of red blood cell (RBC) aging may increase during some types of intensive training and the life span of these cells may be decreased $^{2,3)}$. The mechanism of the RBC life span induced by training or exercise has been reported ${ }^{4-9)}$. However, most of these reports address exercise-induced hemolysis or iron depletion ( $\mathrm{RBC}$ depletion $)^{6,7.10)}$ and direct comparative measurements of key factors affecting the de-

\footnotetext{
1) 日本女子体育大学

干157-8565 世田谷区北烏山8-19-1

2) 東京都神経科学総合研究所

干183-8526 府中市武蔵台2-6

3) スポーツ栄養学研究会 (日本女子体育大学内) ₹157-8565 世田谷区北烏山8-19-1

4) 千葉西総合病院 于270-2251 松戸市金ヶ作107-1

5) 京都大学大学院工学研究科環境工学専攻 干606-8501 京都市左京区吉田本町
}

Japan Women's College of Physical Education, 8-19-1

Kitakarasuyama, Setagaya-ku, Tokyo 157-8565

Tokyo Metropolitan Institute for Neuroscience, 2-6 Musasidai, Hutyuu-city, Tokyo 183-8526

Study group of Sport Nutrition, 8-19-1 Kitakayrasuyama, Setagaya-ku, Tokyo 157-8565

Chibanishi Sogo Byouin, 107-1 Kanegasaku, Matsudo-city 270-2251

Department of Environmental Engineering, Kyoto University, Yoshidahonchou, Sakyoku, Kyoto 606-8501 
gradation and biosynthesis of RBC during training are scarce.

The second enzyme in the processes of RBC biosynthesis is $\delta$-aminolevulinate dehydratase (ALAD). The activity $\delta$-ALAD in the blood is significantly low in animals treated with lead ${ }^{11)}$. Lead poisoning is occasionally associated with iron deficient anemia ${ }^{11-14)}$. Davis and Avram ${ }^{15)}$ confirmed a linear correlation between the proportion of reticulocytes and the activity of RBC $\delta$ - ALAD in adult rats that had been anemic since birth. Therefore, changes in RBC $\delta$-ALAD activity may be a good biomarker of RBC biosynthesis. Here, we compared the effect of body iron stores on the biosynthetic and degradative indices of $\mathrm{RBC}$ after a single session of cycling.

We examined exercise-induced changes in RBC $\delta$-ALAD activity, serum erythropoietin concentration (EPO) and reticulocytes, which are biosynthetic indices of RBC, and in osmotic fragility of $\mathrm{RBC}$ and serum haptoglobin ( $\mathrm{hp}$ ) concentrations, which are indices of degradative factors.

\section{Subjects and methods}

\section{Subjects}

Eight sedentary female college students who had not participated in a regular physical activity for the past 6 months volunteered to participate in this study. All completed a health questionnaire and were excluded if any medication had been taken during six weeks prior to the study or if symptoms of upper respiratory tract infection had been evident within four weeks prior to the study. All volunteers were non-smokers with normal blood pressure, and normal menstrual cycles.

Prior to this experiment, analyses of iron status found that none of the women were anemic (defined as hemoglobin $(\mathrm{Hb})<12 \mathrm{~g} / \mathrm{dl}$ ). Based upon body iron stores indicated by the serum fer. ritin concentration and transferrin saturation, the women were divided into groups with normal body iron stores ( $\mathrm{C}$ group, $\mathrm{n}=5$ ) and with low body iron stores ( $D$ group, $n=3$ ). The D group had either serum ferritin level of less than 12 $\mathrm{ng} / \mathrm{ml}$ or less than $15 \%$ transferrin saturation.

To create appropriate testing conditions, all participants were instructed to refrain from strenuous activity during 24 hours before the experiment and were asked to fast overnight. All studies were implemented from 1 to 2 weeks after menstruation.

Prior to this study, each participant gave written informed consent in accordance with the procedures approved by the Ethics Committees of the Japan Women's College of Physical Education. The results of all measurements were given to the participants.

\section{Determination of peak oxygen consumption}

Values of $\mathrm{O}_{2}$ intake $\left(\mathrm{V}_{2}\right)$ for each individual were determined using a continuous incremental loading test to volitional exhaustion on an electrically braked cycle ergometer (Colibal 400, Lode Co. Ltd., Holland). After standard familiarization and a 5 to $10 \mathrm{~min}$ warm-up procedure, each participant began cycling at 5 watts (W). The work load was increased at $\mathrm{s}$ rate of $25 \mathrm{~W}$ every three minutes until exhaustion. Expired air was col lected continuously using an automated gas analy sis system (Metabolic Measurement Cart 2900 : Sensor Medics Co. Ltd., USA). The concentrations of oxygen and carbon dioxide in the expired air. and the volume of the expired air were monitored throughout the test. A gas analyzer was calibrated to a standard volume of air, concentrations of $\mathrm{O}_{2}$ and $\mathrm{CO}_{2}$, and atmospheric pressure before each exercise session. Minute ventilation, $\dot{\mathrm{VO}}_{2}$ and $\dot{\mathrm{V}} \mathrm{CO}_{2}$ were obtained at 1 -minute intervals. The $\dot{\mathrm{VO}}_{2}$ peak was determined by the highest $\dot{\mathrm{VO}}_{2}$ value attained when an individual could no longer cycle at the specified $50 \mathrm{rpm}$. From the $\mathrm{VO}_{2}$-work rate relationship, the work rate equivalent to $70 \%$ 
$\dot{\mathrm{V}} \mathrm{O}_{2}$ peak was interpolated $(93.5 \pm 4.6 \mathrm{~W})$.

\section{Experimental design}

Participants exercised on a cycle ergometer at $70 \% \dot{\mathrm{VO}}_{2}$ peak for $35.3 \pm 6.4$ (means $\pm \mathrm{SD}$ ) minutes and consumed a mean energy of $248.8 \pm$ $3.1 \mathrm{kcal}$. Environmental conditions during the experiment were maintained at $23 \sim 25^{\circ} \mathrm{C}$ and at $49.9 \pm 0.8 \%$.

Venous blood samples were collected by vene. puncture from an antecubital vein before (pre), immediately after ( 0 hours), then 1,3 and 6 hours after exercise (Fig. 1).

Participants were required to remain fasted until the first blood sample was collected after the exercise. A standardized meal provided 30 and 210 minutes after the exercise consisted of two cooked rice balls (Onigiri ; $300 \mathrm{kcal}$ each) for a total energy intake of $600 \mathrm{kcal}$ during the recovery period.

\section{Dietary analysis}

Food intakes from three days prior to the ex periment were determined by a well-trained dietitian using the 24 hour-recall method. The intakes of individual nutrients were calculated based on the Standard Tables of Food Composition for Japanese $\left(4^{\text {th }} \text { edition }\right)^{16)}$.

\section{Haematological analysis}

Blood samples were collected in EDTA- $2 \mathrm{~K}$ tubes. Hematological parameters including $\mathrm{RBC}$ counts, Hb concentration and hematocrit $(\mathrm{Ht})$ levels were measured using an automated system (Horiba LC-360, Horiba Seisakusho KK, Japan). Percent changes in plasma volume were estimated from pre- and post-exercise $\mathrm{Ht}$ and $\mathrm{Hb}$ values as described by Dill and Costill ${ }^{17)}$.

The following analyses were performed in duplicate. The osmotic fragility of $\mathrm{RBC}$ was mea. sured according to Beutler ${ }^{18)}$ and ${ }^{\circ}$-ALAD activ. ity was assayed using the heparinized RBC fraction as described ${ }^{19.20)}$. Heparinized blood (2 ml) was separated by centrifugation at $3,000 \mathrm{rpm}$ for 10 minutes at $5^{\circ} \mathrm{C}$ and the supernatant $w$ as discarded. The sedimented $\mathrm{RBC}$ were washed three times with $2 \mathrm{ml}$ of cold phosphate buffered saline (pH 7.4), suspended in the same buffer and stored at $-70^{\circ} \mathrm{C}$. Before use, $\mathrm{RBC}$ were incubated at $37^{\circ} \mathrm{C}$ for 30 minutes with $\delta$-aminolevulinic acid. The reaction was stopped with a $\mathrm{TCA}-\mathrm{HgCl}_{2}$ mixture, and color was developed using a modified Ehrlich reagent. Enzyme activity was calculated using the molar absorption coefficient $\left(6.1 \times 10^{4}\right)$ of the final Ehrlich color salt at $553 \mathrm{~nm}$. Results are expressed as nmol porphobilinogen $/ \mathrm{mg} \mathrm{Hb} / \mathrm{hr}$.

Concentrations of serum iron, ferritin, total iron binding capacity (TIBC), EPO and hp were measured at the Medical Lab Co. Ltd. (Tokyo, Japan) as follows : iron by atomic absorption spectrophotometry (SHIMAZU AA 6400-F, Shimazu Co. Ltd., Japan); ferritin, by enzyme-linked fluorescent assay: transferrin iron binding capacity, by Nitroso-PSAP method; EPO, by radioimmuno-

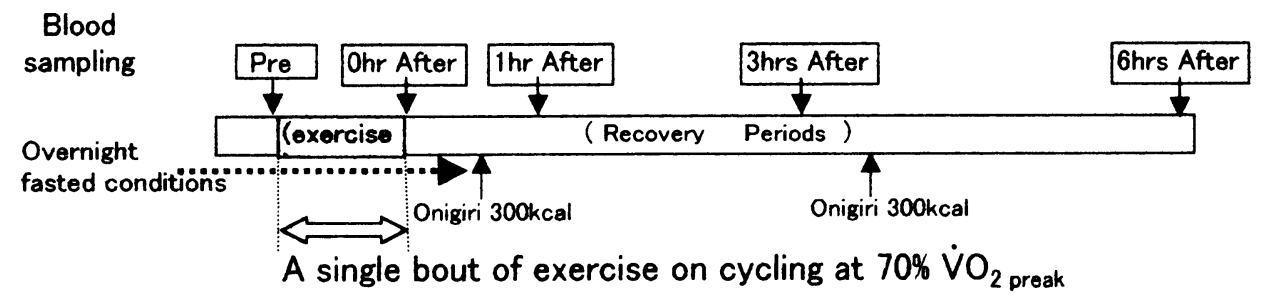

Fig. 1. Experimental design.

Female sedentary students participated in this approved experimental protocol as described in the text. 
assay and hp, by immune- nephelometry using a Nephelometer Analyzer II (Behring, Germany). Transferrin saturation was calculated according to the following equation :

Saturation of transferring $(\%)=100 \times$ serum iron/transferrin iron binding capacity.

Reticulocytes stained with a new methylene blue dye were counted under a light microscope (Alphaphoto-2 YS2-H, Nikon Co. Ltd., JAPAN).

\section{Statistics}

All values are presented as mean values with standard deviations of the mean ( \pm SD). Data were analyzed using a two-factor ANOVA with repeated measures over time, by SPSS 6.0 for Windows statistical software. Multiple-factorial analysis of variance with repeated measurements and Newman-Keuls post hoc comparisons was used to assess differences between groups as well as between values at different time points. A $\mathrm{t}$-test with Bonferroni correction of alpha error was used to make pairwise comparisons when a nearly significant $(\mathrm{p}=0.055)$ main effect was identified by ANOVA. Statistical significance was accepted at $\mathrm{p}<0.05$.

\section{Results}

\section{Characteristics of the participants}

All participants in the present study menstruated normally. Pre-exercise height, body mass or aerobic capacity did not significantly differ between the two groups (Table 1). Hematological tests conducted before the study showed that none of the women had anemia of less than $12 \mathrm{~g} / \mathrm{dl} \mathrm{Hb}$ (Table 2).

\section{Dietary intakes}

Mean daily intakes of energy, protein, carbohy.

Table 1. Comparison of physical characteristics of the participants.

\begin{tabular}{lccccc}
\hline Group & No. & Age(yr) & Height (cm) & Weight(kg) & $\begin{array}{l}\text { VO }_{2} \text { peak } \\
(\mathrm{ml} / \mathrm{kg} \cdot \mathrm{min})\end{array}$ \\
\hline \hline C & 1 & 27 & 160 & 47 & 34.2 \\
& 2 & 23 & 159 & 52 & 35.6 \\
& 3 & 21 & 150 & 48 & 48.7 \\
& 4 & 21 & 155 & 49 & 35.9 \\
& 5 & 21 & 161 & 49 & 35.6 \\
& & $23.0 \pm 2.3^{a)}$ & $157.0 \pm 4.0$ & $49.0 \pm 1.7$ & $38.0 \pm 5.4$ \\
\hline D & 1 & 27 & 168 & 59 & 42.3 \\
& 2 & 22 & 158 & 56 & 31.4 \\
& 3 & 22 & 168 & 60 & 38.1 \\
& & $23.6 \pm 2.3$ & $164.7 \pm 4.7$ & $58.3 \pm 1.7$ & $37.3 \pm 4.5$ \\
\hline
\end{tabular}

a : Values are expressed as means \pm standard deviation.

Table 2. Changes in serum iron, Tf and serum ferritin concentrations.

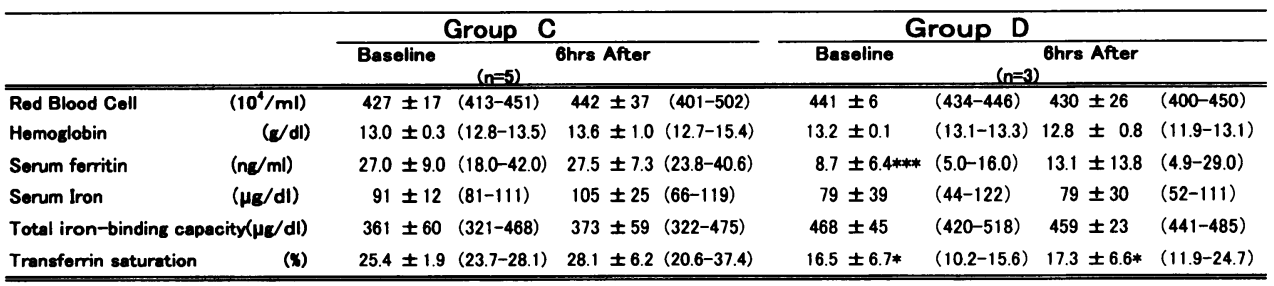

All values are expressed as means \pm standard deviations.

Significantly lower values in group D than in group $C(* * * ; p<0.001, * ;<0.05)$.

Serum iron, transferrin saturation and ferritin concentrations were not affected by this exercise. 
drate, iron, vitamin $\mathrm{A}$ and vitamin $\mathrm{C}$ tended to decrease in the group D compared to group C, but not significantly. Briefly, energy intakes in the D and $C$ groups were $1684 \pm 410 \mathrm{kcal} / \mathrm{day}$ and 1867 $\pm 553 \mathrm{kcal} / \mathrm{day}$, protein intakes were $56.8 \pm 25.9$ $\mathrm{g} / \mathrm{day}$ and $56.9 \pm 21.5 \mathrm{~g} / \mathrm{day}$, carbohydrate in . takes were $239 \pm 64 \mathrm{~g} /$ day and $261 \pm 66 \mathrm{~g} /$ day, iron intakes were $7.4 \pm 3.6 \mathrm{mg} / \mathrm{d}$ ay and $14.8 \pm 19.1$ $\mathrm{mg} / \mathrm{day}$, vitamin A intakes were $1732 \pm 1184$ $\mathrm{IU} /$ day and $2542 \pm 2806 \mathrm{IU} /$ day, and vitamin $\mathrm{C}$ in . takes were $41.9 \pm 10.3 \mathrm{mg} / \mathrm{d}$ ay and $43.8 \pm 24.1$ $\mathrm{mg} /$ day, respectively.

\section{Haematological changes}

Mean values of $\mathrm{RBC}$ and $\mathrm{Hb}$ were not signifi. cantly different between the two groups throughout the study (Table 2). In four of five women in group $C$ and two of three in group D, $\mathrm{RBC}$ counts tended to increase within 6 hours after exercise compared with the beginning of this study (baseline). However, this tendency was not significant in either group. Mean corpuscular haemoglobin $(\mathrm{MCH})$, mean corpuscular volume (MCV) and mean corpuscular haemoglobin concentrations $(\mathrm{MCHC})$ did not significantly change during the study in either group (data not shown).

Serum ferritin and transferrin saturation were significantly lower in group $D$ than in group $C$ at the baseline of this study (Table 2). On the other hand, a single session of cycling exercise load did not affect the body iron status in terms of serum ferritin and iron, total iron binding capacity or transferrin saturation in both groups.

The single exercise session tended to increase $\mathrm{RBC}, \mathrm{Hb}$, serum iron, total iron binding capacity, and transferrin saturation at 6 hours after exercise compared with the baseline in the same four of five women in group $\mathrm{C}$, but serum ferritin in the three of the five in this group decrease at 6 hours after exercise. In group D, serum ferritin. serum iron, $\mathrm{RBC}$ and transferrin saturation tended

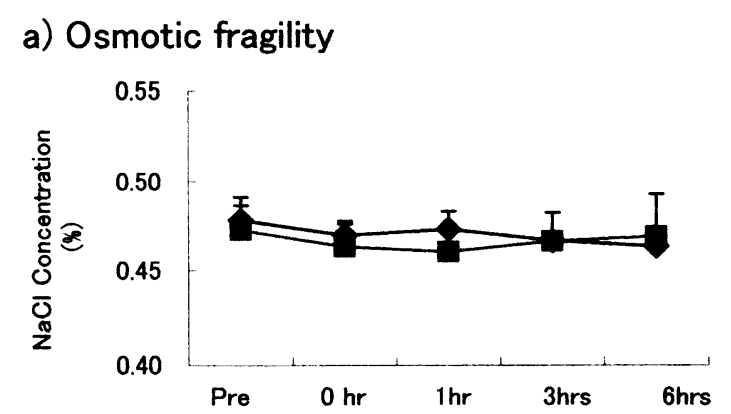

b) $h p$

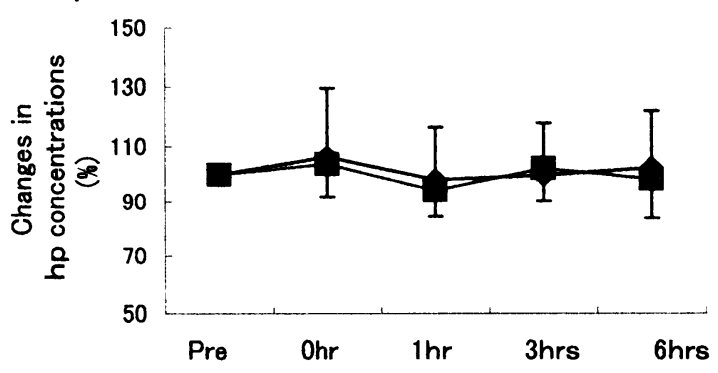

Fig. 2. Changes in osmotic fragility of RBC and haptoglobin concentrations induced by a single session of cycling exercise.

All values are expressed as means \pm SD. Abbre. viations : $\boldsymbol{\nabla}$, group $\mathrm{C} ; \boldsymbol{\square}$, group D. Osmotic fra. gility is expressed as $\mathrm{NaCl}$ concentration required for $50 \%$ hemolysis. Osmotic fragility and hp concentrations throughout the study did not differ between groups C and D.

to increase in two of three women at 6 hours after exercise compared to the baseline.

\section{RBC degradation}

Osmotic fragility of $\mathrm{RBC}$ is expressed as $\mathrm{NaCl}$ concentration required to induce $50 \%$ hemolysis. This concentration remained unchanged throughout the study in both groups. Osmotic fragility did not significantly differ between the groups and hp concentrations in groups $\mathrm{C}$ and $\mathrm{D}$ did not significantly differ and remained un changed throughout the study (Fig. 2).

\section{RBC biosynthetic capacity}

Pre-exercise $\delta$-ALAD activities in groups D and $\mathrm{C}$ were respectively $50.6 \pm 5.4 \mathrm{nmol} / \mathrm{mg}$ 


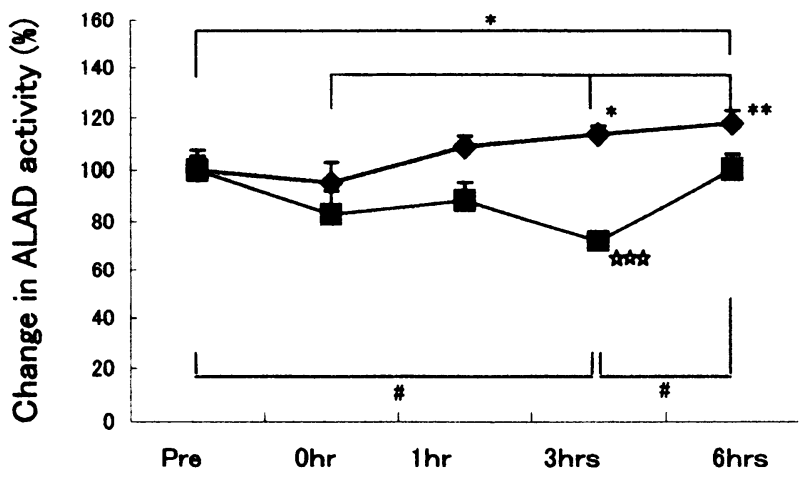

Fig. 3. Changes in $\delta$-ALAD activities.

Values are expressed as means $\pm \mathrm{SD}$.

Significant differences between the groups identified by ANOVA $(\mathrm{p}<0.001)$.

In group $C(\bullet), \delta-\operatorname{ALAD}$ activity at $3\left(^{*}, \mathrm{p}<0.05\right)$ and 6 hours $(* *, \mathrm{p}<0.01)$ after exercise was significantly higher than that immediately after exercise. ALAD activity was sig. nificantly increased at 6 hours after exercise compared with pre-exercise level $\left({ }^{*}, \mathrm{p}<0.05\right)$.

In group $\mathrm{D}(\boldsymbol{\square}), \delta$-ALAD activity at 3 hours after exercise was significantly decreased as compared with pre $\left({ }^{\#} ; \mathrm{p}<\right.$ $0.05)$ and 6 hours $\left({ }^{\#} ; \mathrm{p}<0.05\right)$ after exercise.

Significantly lower values at 3 hours after exercise in group D than in group $C(p<0.001)$.

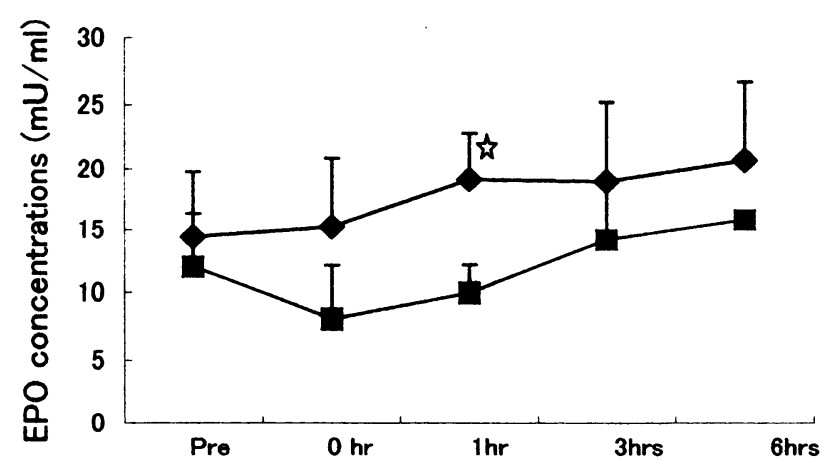

Fig. 4. Effect of a single session of cycling exercise on erythropoietin concentrations.

Abbreviations: $\diamond$, group C; $\boldsymbol{\square}$, group D. Values are ex . pressed as means $\pm \mathrm{SD}$.

Significant difference between groups by ANOVA $(p<0.05)$.

. Significant difference between groups $(p<0.001)$.

Erythropoietin concentration at 1 hour after exercise was significantly higher in group $\mathrm{C}$ than in group $\mathrm{D}$.
$\mathrm{Hb} / \mathrm{hr}$ and $43.2 \pm 12.5 \mathrm{nmol} / \mathrm{mg} \mathrm{Hb} / \mathrm{hr}$ with no significant differences between the groups. However the $\delta$-ALAD activity during study significantly differed between the groups (ANOVA $\mathrm{p}<0.001$, Fig. 3 ).

The $\delta$-ALAD activity in group $C$ was significantly higher at $3(\mathrm{p}<0.05)$ and 6 hours $(\mathrm{p}<0.01)$ after exercise compared with that immediately after exercise. At 6 hours after exercise, the activity also significantly increased compared with the pre-exercise level $(\mathrm{p}<0.05)$.

On the other hand, the activity in group $D$ tended to decrease from pre to 3 hours after exercise, and that at 3 hours after exercise was significantly lower than that of the pre-exercise time point $(\mathrm{p}<0.05)$. At 6 hours after exercise, the activity significantly increased compared with 3 hours after exercise $(\mathrm{p}<0.05)$ and was similar to the pre-exercise value.

At 3 hours after exercise, $\delta$-ALAD activities significantly differed between the two groups $(p<0.001)$, but not at 6 hours after exercise.

The EPO concentrations significantly differed between the two groups during the study (ANOVA, $\mathrm{p}<0.05 ;$ Fig. 4 ). The EPO concentrations in group $C$ gradually, but not significantly increased from pre to 6 hours after exercise. Although EPO concentrations did not significantly change in group D dur. ing the study, they gradually increased from 0 to 6 hours after exercise. Thus, EPO concentrations at 1 hour after exercise were significantly higher in group $\mathrm{C}$ than in group D $(\mathrm{p}<0.001)$.

The pre-exercise counts of reticulocytes were higher in group D than in group C $(28.7 \pm 5.9 \%$ vs. $19.6 \pm 9.2 \%$, respectively ; $\mathrm{p}<0.08)$. The increasing rates of reticu- 


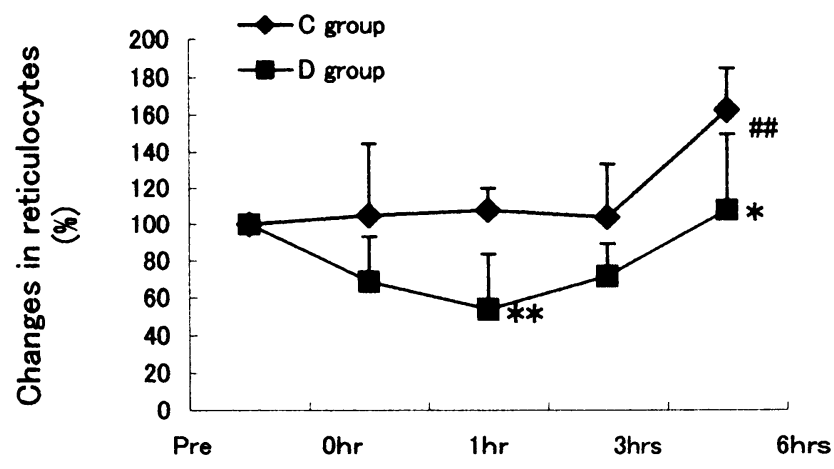

Fig. 5. Changes in reticulocyte counts induced by a single session of cycling exercise.

Abbreviations: $\bullet$, group C; $\square$, group D. Values are means \pm SD.

Time $(\mathrm{p}<0.01)$ and Group $(\mathrm{p}<0.001)$ differences were identi. fied by two-way ANOVA.

Significantly lower values in group $\mathrm{D}$ than in group $\mathrm{C}(* *$; $\mathrm{p}<0.01, * ; \mathrm{p}<0.05)$.

Group C, 6 hours after exercise: others $(\# ; p<0.01)$.

Group D, no significant differences among various time points.

locytes were significantly higher in group $C$ than in group D throughout the study (ANOVA p $<$ 0.001 ; Fig. 5). Reticulocyte counts in group $\mathrm{C}$ were the highest at 6 hours after exercise compared with that at other time points $(p<0.01)$. In group $D$, reticulocyte counts at 1 hour after exercise were the lowest, whereas the numbers at pre- and at 6 hours after exercise were essentially identical. Therefore, the reticulocyte numbers statistically differed between the two groups at $1(\mathrm{p}<0.01)$ and 6 hours $(\mathrm{p}<0.05)$ after exercise.

\section{I . Discussion}

Despite the small study population, we uncovered novel information regarding RBC biosynthesis and destruction during a single session of cycling exercise.

The average life span of RBC may be decreased during some forms of intensive training ${ }^{2.3)}$. Magazanik et al. ${ }^{21)}$ investigated the effects of an intensive physical training program involving both isometric and isotonic activities on the body iron status of 8 females and 11 males. They found that body iron status declined (serum ferritin level, serum iron concentration, total iron binding capacity) after 2 weeks of training, and pointed out that the body iron status of athletes engaged in some intensive training might worsen.

Some endurance training, particularly running, increases rates of RBC destruction $^{22)}$, loss of iron thru sweat and urine, and rates of gastrointestinal or urinary tract bleeding. Furthermore, exerciseinduced hemolysis has occurred after marathons ${ }^{23)}$, ultramarathons ${ }^{1,17)}$ and triathlons ${ }^{7)}$. As the blood circulates, RBC shrink and swell, which may lead to physical damage. Furthermore, changes in blood osmolality may adversely affect RBC deformability and passage through the mic. rocirculation. Foot-strike hemolysis, renal ischemia, hypoxic damage to the kidney and the release of a hemolyzing factor have also been proposed as causes of exercise-induced hemolysis. Increased concentrations of prostaglandin $\mathrm{E}^{24)}$ and/or catecholamines $^{25)}$ can influence the osmotic properties of RBC. Accordingly, changes in the osmotic properties of $\mathrm{RBC}$ during exercise may be a good index of RBC deformability.

The values of $\mathrm{RBC}, \mathrm{Hb}, 50 \%$ hemolysis and hp did not significantly change in groups $C$ and $D$ under our experimental conditions, indicating that exercise-induced hemolysis had not developed. Since our exercise loading was at $70 \% \mathrm{VO}_{2}$ peak for $35.3 \pm 4.8$ (SD) minutes and the mean energy consumption was $248.8 \pm 3.1(246 \sim 252) \mathrm{kcal}$, this level of exercise loading appears relatively mild and not particularly intensive. This suggests that cycle-ergometer exercise under our experimental conditions is not directly connected with hemolytic factors such as foot-strike stress ${ }^{23}$ or lysolecithin ${ }^{26)}$, and that RBC degradation estimated by osmotic fragility and hp concentrations 
is independent of $70 \% \mathrm{~V}_{2}$ peak of cycling exercise loading.

$\mathrm{RBC}$ biosynthesis estimated by $\delta$-ALAD activity, reticulocytes and EPO concentration increased after exercise in group $C$, but not in D group. Abraham et al. ${ }^{27)}$ reported that $\delta$-ALAD activity is elevated in iron-deficient liver cells. The present study found that the pre-exercise $\delta$-ALAD activity tended to increase in group $D$ than in group $C$, but not significantly. In addition, the effect of exercise upon the $\delta$-ALAD activity in group $C$ was significantly higher at 3 and 6 hours thereafter. This increase in $\delta$-ALAD activity in group $C$ may be caused by accelerated neural functions during exercise. Physical activity stimulates the functional activity of the central nervous system and the release of hormones such as adrenocorticotrophic hormone (ACTH), norepinephrine and cortisol. It seems likely that $\delta$ ALAD activity is influenced by neural activity or hormones $^{28)}$.

Reduced tissue oxygen tension (renal and hepatic) might be a primary factor stimulating EPO synthesis. Under our experimental conditions, EPO concentrations in group $C$ gradually in creased from 1 to 6 hours after exercise compared with values at pre and immediately after exercise, but this was not evident in group D. Schmidt et al. ${ }^{8)}$ examined the effect of exercise regimens on serum immunoreactive EPO concentration and indicated that submaximal exercise on a cycle ergometer for 60 minutes at $60 \%$ of $\mathrm{VO}_{2}$ peak, had no immediate effect on serum EPO. However, the EPO level was increased at one and two days after exercise ${ }^{29)}$. This value in our study was high at 3 to 6 hours after exercise in the group $C$, but not immediately thereafter. In D group, EPO concentrations decreased from pre- to 1 hour after exercise, and increased thereafter to 6 hours after exercise. The EPO concentrations at 6 hours after exercise were very similar to the pre-exercise level. The change in EPO concentrations during recovery periods after cycling exercise was quite different between the two groups.

Recombinant human erythropoietin (rh-Epo) has been used to improve anemia due to chronic kidney disease, but an iron deficiency is the most common cause of resistance to rh-Epo therapy, contributing to ineffective erythropoiesis ${ }^{30}$. Furthermore, serum EPO levels are partially controlled by sympathetic outflow to the kidney. Patients with multiple systemic atrophy associated with dysautonomia, are EPO-deficient ${ }^{31)}$. As some physical activities stimulate the central nervous system, low body iron stores might repress serum EPO levels elevated by a single session of cycling exercise.

Reticulocyte counts were highest at 6 hours after exercise in group $C$. The increased EPO levels may be related to the release of reticulocy. tes from bone marrow into the peripheral blood ${ }^{29)}$, suggesting that submaximal exercise enhances erythropoiesis. On the other hand, the reticulocyte count was significantly lower in group $D$ than in group $C$ throughout this study $(\mathrm{p}<0.001)$ (Fig. $5)$. Changes in reticulocyte counts in groups $C$ and D closely corresponded with changes in EPO.

These results suggest that body iron stores affects the capacity of RBC biosynthesis after exercise, which may provide a suitable rationale to prevent body iron stores from decreasing. Iron plays an important role in regulating intercellular energy metabolism and oxygen transport. Enhanced biosynthesis of new RBC may increase the need for RBC synthetic materials such as iron, protein and vitamin B groups. Therefore, individuals with insufficient body iron stores who perform some types of exercise cannot supply these materials, especially iron. The present findings of the effects of a single session of exercise on $\delta$-ALAD activity, EPO and reticulocytes in group $D$ might result from an adaptation to iron 
deficiency. For individuals with low body iron stores to adapt to some types of exercise, treat ment for iron deficiency with sufficient intake of iron and nutrients should be a priority.

In summary, $70 \% \dot{\mathrm{VO}}_{2}$ peak of cycling exercise did not cause hemolysis regardless of the condi. tion of the body iron stores. A subsequent iron deficiency did not arise either, but the EPO concentration and number of reticulocytes increased. The activity of $\delta$-ALAD might be enhanced by a single session of cycling exercise under normal body iron stores. Furthermore, decreased body iron stores seem to affect RBC biosynthesis en hanced by a single session of cycling exercise.

Further examinations are required to confirm this notion.

(Accepted Jan. 30, 2002)

\section{References}

1) Seiler D, Nagel D, Franz H, Helstern P, Leitzmann $P$, Jung $K$. Effects of long-distance running on iron metabolism and hematological parameters. Int. J. Sports Med. (1989), 10, 357-362.

2) Smith JA. Exercise, training and red blood cell turnover, Sports Med. (1995), 19, 9-31.

3) Yoshimura H, Inoue T, Yamada T, and Shiraki K. Anemia during hard physical training (sports anemia) and its causal mechanism with special refer. ence to protein nutrition. Wld. Rev. Diet (1980), 35 , 1-86.

4) Clement DB, Asmundson RC, Medhurst CW Haemoglobin values: comparative survey of the 1976 Canadian Olympic team. Can. Med. Assoc. J. (1977), 117, 614-616.

5) Elliot DL, Goldberg L and Eichner ER. Hematuria in young recreational runner. Med. Sci. Sports Exerc. (1991), 23, 892-894.

6) Lindemann R, Ekanger R, Opstad PK, Nummestad $\mathrm{M}, \mathrm{Ljosland} \mathrm{R}$. Hematological changes in normal men during prolonged severe exercise. Am. Corr. Ther. J. (1978), 32, 107-110.

7) O'Toole ML, Hiller WDB, Roalstad MS, Douglas PS. Hemolysis during triathlon races: its relation to race distance. Med. Sci. Sports Exerc. (1988), 20, 272-275.

8) Schmidt W, Maassen N, Trost F, Boning B. Training induced effects on blood volume, erythrocyte tur. nover and haemoglobin oxygen binding properties. Eur. J. Appl. Physiol. (1988), 57, 490-498.

9) Selby GB, Eichner ER. Endurance swimming, intra. vascular hemolysis, anemia, and iron depletion. Am. J. Med. (1986), 81, 791-794.

10) Smith JA. Exercise, training and red blood cell turnover, Sports Med. (1995), 19, 9-31.

11) Gupta V, Gill KD. Influence of ethanol on lead distribution and biochemical changes in rats exposed to lead. Alcohol (2000), 20, 9-17.

12) Aly MH, Kim HC Renner SW, Boyarsky A, Kosmin M, Pagli DE. Hemolytic anemia associated with lead poisoning from shotgun pellets and the response to Succimer treatment. Am. J. Hematol. (1993), 44, 280-283.

13) Kaul B, Rasmuson JO, Olsen RL, Chanda CR, Slazh. neva TI, Granovsky EI, Korchevsky AA. Blood lead and erythrocyte protoporphyrin levels in Kazakh. stan. Indian J. Pediatr. (2000), 67, 87-91.

14) Osterode W, Barnas U, Geissler k. Dose dependent reduction of erythroid progenitor cells and in. appropriate erythropoietin response in exposure to lead: new aspects of anaemia induced by lead. Occup. Environ. Med. (1999), 56, 106-109.

15) Davis JR. Avram MJ. Developmental changes in delta-aminolevulinic acid dehydratase (ALAD) activity and blood reticulocyte percent in the de. veloping rat. A brief note. Mech. Ageing Dev. (1978), 7, 123-129.

16) The Science and Technology. Standard Tables of Food Composition in Japan, 4th ed. Hitotsubashi Shuppan, Tokyo, 1998.

17) Dill DB, Costill DL. Calculation of percentage changes in volumes of blood, plasma, and red cells in dehydration. J. Appl. Physiol. (1974), 37, 247248.

18) Beutler E, Kuhl W, West C. The osmotic fragility of erythrocytes after prolonged liquid storage and after reinfusion. Blood (1982), 59, 1141-1147.

19) Granick JL, Sassa S, Levere RD and Kappas A. Correlation between the ratio of activated to inactivated 0 -ALAD of whole blood and the blood lead levels. Biochem. Med. (1973), 8, 149-159.

20) Gupta V. Gill KD. Influence of ethanol on lead distribution and biochemical changes in rats exposed to lead. Alcohol (2000), 20, 9-17.

21) Magazanik A, Weinstein Y, Dlin RA, Derin M, Schwartzman S, Allalouf D. Iron deficiency caused by 7 weeks of intensive physical exercise. Eur. J. Appl. Physiol. Occup. Physiol. (1988), 57, 198-202.

22) Witte DL. Can serum ferritin be effectively inter. preted in the presence of the acute/phase response? Clin. Chem. (1991), 37, 484-485.

23) Jordan J, Kiernan W, Merker HJ, Wenzel M, Beneke $\mathrm{R}$. Red cell membrane skeletal changes in marathon runners. Int. J. Sports Med. (1998), 19, 16-19.

24) Rasmussen H, Lake W. Allen JE. The effect of catecholamine and prostaglandins upon human and rat erythrocytes. Biochim. Biophys. Acta (1975), 
411, 63-73.

25) Staubli M, Roessler B. The mean red cell volume in long distance runners. Eur. J. Appl. Physiol. (1986). 55, 49-53.

26) Shiraki K. The effect of spleenectomy on sports anemia. J. Physiol. Soc. Jap. (1968), 30, 96-108.

27) Abraham NG, Lutton JD, Levere RD. Heme metabolism and erythropoiesis in abnormal iron states: role of $\delta$-aminolevulinic acid synthase and heme oxygenase. Exp. Hematol. (1985), 13, 838-843.

28) Flora GJ, Khanna VK. Seth PK. Changes in neurotransmitter receptors and neurobehavioral variables in rats co-exposed to lead and ethanol. Toxicol.
Lett. (1999), 109, 43-49.

29) Schmidt W, Eckardt KU, Hilgendorf A, Strauch S, Bauer C. Effects of maximal and submaximal exer. cise under normoxic and hypoxic conditions on serum erythropoietin level. Int. J. Sports Med. (1991), 12, 457-461.

30) Drueke T. Hyporesponsiveness to recombinant human erythropoietin. Nephrol. Dial. Transplant. (2001), 16, 25-28.

31) Winkler AS, Marsden J, Parton M, Watkins PJ, Chaudhuri KR. Erythropoietin deficiency and anaemia in multiple system atrophy. Mov. Disord. (2001) , 16, 233-239. 